\title{
How Tight is Too Tight? A Look at Welfare Implications of Distortionary Policies in Uzbekistan
}

\author{
Edward R. Gemayel and David A. Grigorian ${ }^{1}$ \\ International Monetary Fund
}

\begin{abstract}
Since independence in 1991, Uzbekistan has pursued a gradual approach to the transition from planned to market economy. This approach relied heavily on trade controls, directed credit, and large public investments. In addition, a number of financial sector measures were instituted that distorted resource allocation and increased transaction costs. As a result, while possibly preventing the contraction of output in the early 1990s, these policies led to disappointing economic outcomes and social conditions later on. The paper reviews the underlying distortions and presents survey-based evidence to support their existence and their detrimental impact on economic activity. Looking forward, the paper-using a representative agent framework to model existing financial sector distortions-offers some guidance regarding the likely implications of eliminating these distortions on key aggregate variables. It suggests that the elimination of these distortions will be welfare enhancing and will lead to higher levels of investment and capital stock.
\end{abstract}

JEL Classification: E50, P23, P27

Keywords: financial sector distortions, transition, Uzbekistan

\section{Introduction}

Uzbekistan is strategically located in Central Asia, at the crossroads of the ancient Silk Road between China and Europe. Of the 15 independent states that emerged from the breakup of the Soviet Union in 1991, Uzbekistan is the third largest in population (about 26 million) and the fourth largest in land area (448 thousand square kilometers). During the Soviet period, Uzbekistan was developed as a leading center for cotton production, capitalizing on its vast water resources for irrigation.

Since independence, the Uzbek authorities have opted for a gradual approach to reforming their economy. Their strategy aimed at building a socially oriented market economy, and developing industrial and manufacturing capacity in a predominantly agricultural economy using substantial and direct central guidance. To that end, the government has adopted an import-substitution strategy, particularly since 1997, that has relied heavily on administrative intervention and a restrictive foreign exchange and trade regime.

Unfortunately, this gradual reform strategy relied heavily on three interventionist pillars, most of which have their roots in Soviet planned-economic practices: exchange and trade controls, directed resource allocation, output targets (especially agricultural) and sizable public investment. Some of these controls and restrictions, discussed in detail in the paper, are quite unique. As a result, while these policies may have prevented output from contracting in the early 1990s, they led to disappointing economic and

\footnotetext{
${ }^{1}$ Corresponding author (dgrigorian@imf.org). We would like to thank Sena Eken, Galina Kostina, Martin Raiser, Andriy Storozhuk, John Wakeman-Linn, and two anonymous referees for helpful comments. Remaining errors are our own.
} 
social conditions later on. ${ }^{2}$ Industrial growth was very low and uneven. While some new industries were promoted, many others have ceased operations or are operating below capacity. Production and exports witnessed little diversification. The government's presence remains strong in many areas, with governance and capacity issues providing reasons for concern to the international community. ${ }^{3}$ Furthermore, the opacity and unpredictability of government policies continue to hinder domestic economic activity (IFC, 2004) and foreign investment. Uzbekistan lags behind most transition economies in terms of market development, large-scale privatization, and corporate governance.

Zettelmeyer (1998) found that Uzbekistan's good output performance during the early 1990s was mainly due to a combination of low initial industrialization, (scale of) cotton production, and self-sufficiency in energy. These three elements more than offset the impact of the government's poor macroeconomic and structural policies. This conclusion that the government's public investment and gradualist reform program were not the driving forces behind the relatively favorable output performance is also repeated in Taube and Zettelmeyer (1998).

The government's interventionist and distortionary policies were also reflected in the financial sector-dominated by state-owned banks-and in monetary and exchange rate policies. The legacy of administratively-determined interest and exchange rates and limits to access to cash resulted in deteriorating confidence in the financial system. This is reflected in the low level of monetization and heavy reliance of the banking sector on foreign loans as a liability base. ${ }^{4}$ Ranaweeva (2003) shows that the disequilibria in the product and money markets - in an environment of multiple exchange rates, administrative controls, and import restrictions - were the major forces driving inflation dynamics in Uzbekistan. In turn, Rosenberg and de Zeeuw (2000) found that Uzbekistan's multiple exchange rate regime transferred about 16 percent of GDP from exporters to importers and generated identifiable welfare losses in the range of 2-8 percent of GDP on import markets and up to 15 percent on export markets.

However, the government has addressed some of these problems since 2000. It has successively reduced exchange market distortions and introduced currency convertibility, tightened fiscal and monetary policies, initiated the restructuring of farms into leaseholds, and followed a more conservative borrowing path. It has also taken steps to improve the business environment, including the introduction of a unified tax, streamlined registration procedures, fewer business inspections, and relaxed foreign

\footnotetext{
2 After the breakup of the Soviet Union, Uzbekistan recorded the smallest output decline among all the CIS countries and was the first country to resume growth. This, however, did not translate into improvements in living standards and poverty remained high. Berengaut and Elborgh-Woytek (2005) and Pomfret (2003) are useful references for placing Uzbekistan's institutional, social, and output developments in the context of those in other transition countries.

${ }^{3}$ While the discussion of governance, democracy, and human rights dimension is outside of the scope of this paper, a few points could be of relevance here. The Economist Intelligence Unit has recently ranked Uzbekistan 160th out of 167 countries worldwide in terms of democracy (EIU, 2006), with the Transparency International ranking the country 143rd out of 159 countries in terms of corruption perception (TI, 2006). While generally stable, the political environment is tense, with social discontent, stemming from widespread poverty and excessive government interventions, having taken the form of riots in the past. The first parliamentary elections, which took place in December 2004, were seen by observers as neither free nor fair and the opposition parties were barred from participating in it.

${ }^{4}$ In 2004, foreign loans constituted approximately 53 percent of the banking sector's total liabilities, or 2.5 times its capital base.
} 
exchange surrender requirements for exports. ${ }^{5}$ On the financial sector side, in 2004 and early 2005, the government implemented new measures and introduced legislationincluding two presidential decrees-aimed at liberalizing and further reforming the sector. Most notably, these measures included the relaxation and reported complete removal of cash constraints and the clearance of all wage and pension arrears (see Appendix III). If implemented credibly and permanently, and in combination with macroeconomic stability, these structural measures could help Uzbekistan achieve sustained higher growth in the years ahead.

This paper reviews the recent developments and underlying distortions in monetary and financial policies in Uzbekistan, most notably cash shortages and convertibility problems. It describes the implications of these distortions on the behavior of agents and the aggregate economic activity in Uzbekistan. Looking forward, the paper offers some guidance regarding the likely implications of eliminating the observed distortions on key aggregate variables.

The paper is structured as follows. Section II provides an overview of observed irregularities, while presenting the official rationale behind keeping in place the policies responsible for these irregularities. Section III discusses how the behavior and incentives of agents - consumers, enterprises, and financial intermediaries - change in response to these distortions and provides the rationale behind this paper's modeling of the Uzbek economy. The discussion in Sections II and III draws upon a population survey conducted jointly by the World Bank and the International Monetary Fund in summer 2005-within the framework of their surveillance of economic policies in Uzbekistan-to help reveal the extent and implications of financial sector distortions in Uzbekistan. (Appendix I provides a snapshot of relevant survey outcomes). Section IV, in turn, outlines (based on the predictions of a representative agent model) the implications that permanently lifting the observed restrictions would likely have on aggregate output, domestic consumption, trade, and welfare. Finally, Section V offers some policy recommendations.

\section{Description of Prevailing Distortions}

\section{a) Cash Shortages}

During the past two years, following the liberalization of the exchange rate (see below), Uzbekistan has substantially tightened policies aimed at restricting cash in circulation. The government's motivation behind these policies is to control inflation, curb the shadow economy, narrow the gap between the official and black market exchange rates, and strengthen tax collection. In the government's view, what drives inflation is the amount of cash in circulation (and not broader monetary aggregates), hence the desire to limit availability of cash to curb inflationary pressures. ${ }^{6}$

Commercial banks' limited access to their correspondent accounts at the Central Bank of Uzbekistan (CBU) is the main element of the policy to restrict cash in

\footnotetext{
5 Barriers to doing business, however, remained sizable, with reports of serious harassment and persecutions of entrepreneurs surfacing until riots broke out in Kokand in 2004.

${ }^{6}$ Not surprisingly, these policies were not successful in bringing inflation down. Despite extensive cash restrictions, Consumer Price Index increased by an estimated 18.8 percent in 2005 (following an increase of 15.5 percent in 2004), while the Producer Price Index and GDP deflator grew by 28.2 and 16 percent, respectively.
} 
circulation. Banks are routinely unable to withdraw cash from their correspondent accounts at the CBU despite having sufficient balances in their accounts. This in turn limits their ability to meet their customers' legitimate requests to withdraw deposits. ${ }^{7}$ In addition, bank customers - individuals and businesses — are restricted in their ability to pay for current expenditures, due to the lack of non-cash-transacting retail outlets (see below), and to pay for their inputs (including labor), respectively. The situation is exacerbated by the fact that legal entities and individuals engaged in retail trade are required to deposit all daily cash receipts above a small threshold on a daily basis to their bank through a special cash collection service. These problems have been aggravated by related arrears on pensions and civil service wages, which have also been the result of attempts to limit cash in circulation. ${ }^{8}$

Direct evidence of cash shortages is reported by a wide range of market participants and non-governmental entities and individuals. Figures A-1 and A-2 depict the extent and the frequency of problems experienced by individuals while attempting to access their cash in banks. While in capital city of Tashkent the percentage of respondents with difficult or no access to their cash is 66 percent, in other cities included in the survey that share is between $80-85$ percent. In addition, more than half of respondents in all four cities report that they face cash withdrawal limits of 50,000 sum $^{9}$ (approximately $\$ 50$ ). Indirect evidence of these restrictions is found in the premia charged for non-cash payments over cash transactions. (Figure A-3 shows the distribution of premia paid by respondents for non-cash transactions).

\section{b) Convertibility Problems}

Uzbekistan's acceptance of the obligations of Article VIII of the IMF's Articles of Agreement in October 2003 was a major step toward liberalizing the foreign exchange market. Businesses in general have since had access to foreign exchange for all current account transactions, in most cases without major restrictions or delays. However, despite the CBU's commitment to currency convertibility, some problems still exist.

These problems are largely twofold. First, enterprises reportedly have some difficulties converting sums into foreign exchange, since the CBU makes foreign exchange available for the purchase of consumer goods only during the first few days of each month. Any outstanding applications for conversion after this initial period are held until the next month. Second, the conversion for some goods faces longer delays than others. ${ }^{10}$ Some reports also indicate that the authorities are prohibiting conversion to finance pre-payment for some imports. The $\mathrm{CBU}$ denies that convertibility restrictions exist, despite confirmation from local and international businessmen, private bankers, and diplomats. ${ }^{11}$

Households too appear to experience difficulties converting foreign exchange into sums and vice versa (Figure A-4): 38 percent of the respondents were not able to

\footnotetext{
${ }^{7}$ While this practice is common in Uzbekistan, it is highly unlikely that in any other country a bank which is unable to service its depositors would remain open.

${ }^{8}$ Table A-2 states that wage and pension arrears are the most severe problem experienced by respondents.

${ }^{9}$ Sum (pronounced "soum") is Uzbekistan's national currency.

10 The authorities deny the existence of a policy to delay conversion but suggest that some delays happen for purely technical reasons.

${ }^{11}$ If these restrictions were to be confirmed, this would constitute a breach of Article VIII of the IMF's Articles of Agreement.
} 
exchange dollars into sums on their first attempt. This may partially be explained by the fact that there are typically long lines in front of exchange bureaus, as reported in Figure A-5. While exchanging sums into foreign exchange appears to be problematic due mainly to convertibility issues (stemming from the CBU's foreign reserve accumulation targets, see below), reverse transactions (i.e., conversion of foreign exchange into sums) are typically turned down because of the lack of cash sums in exchange bureaus.

\section{c) Other Distortions}

Distinction between cash and non-cash transactions: Uzbekistan's Civil Code requires that all transactions between enterprises and/or individual entrepreneurs must be settled in non-cash form, thus suggesting that cash and non-cash payments are not substitutes. While the authorities argue that the reasons for such a requirement are to combat shadow economic activity, prevent money laundering, and enhance tax collection, the business community unanimously complains that these distinctions impede normal economic activity. ${ }^{12}$

Debit cards (or "plastic cards"): During the second half of 2004, the Uzbek authorities took major steps to encourage the use of plastic cards for payments throughout the country. In particular, a Council of Ministers decree ${ }^{13}$ was issued that required banks to establish plastic card payment terminals in retail establishments in Tashkent. All such establishments above a certain threshold were being mandated to install these terminals at their own expense. ${ }^{14}$ While the use of such electronic payment mechanisms is desirable, the voluntary nature of such a move is of great importance, as it is the only way to encourage the development of a market-oriented banking system. This process requires payment infrastructure, which is still being developed and is not available on a wide scale. ${ }^{15}$ In addition, these cards are seen by the general population as another attempt to remove cash from circulation. ${ }^{16}$

Surrender requirements: Current regulations impose a 100 percent foreign exchange surrender requirement on centralized exports of cotton and gold, and a 50 percent surrender requirement-with some exemptions mainly for small and medium enterprises - on non-centralized exports. In addition, reports indicate that the interbank sales of foreign currencies are prohibited..$^{17}$

Other restrictions: To limit the available liquidity in the financial system and monitor cash flows, the CBU requires all retail businesses to have bank accounts and

12 Anecdotal evidence offers some insight into the nonsensical nature of the distinction between cash and non-cash payments. For example when a business owner invites a client to a restaurant for dinner, this process would apparently require that a contract be signed between the business owner and the restaurant, prior to the dinner, for the money to be transferred from the business owner's account to the restaurant's account. Of course, if the restaurant bill exceeds the expected amount, a new contract would have to be signed!

${ }^{13}$ Council of Ministers Decree No 445 of September 24, 2004.

${ }^{14}$ In addition, the government had an initial plan to make it obligatory for employers to channel initially a small share of wages into plastic card accounts. However, these plans were abandoned in December 2004, after recognizing the need for additional infrastructure.

15 The use of debit cards is extremely limited in Uzbekistan, since only a handful of retail outlets in central urban locations carry ATM/plastic card terminals to enable non-cash payments. In addition, due to the fact that deposits in plastic card accounts are highly illiquid, they are not popular among consumers.

16 The illiquidity of plastic card money is also reflected in the way CBU classifies them as part of "other deposits", which are neither part of M1 nor M2.

17 The CBU denied these restrictions, and has issued a circular to commercial banks clarifying their rights in this area. 
deposit their cash earnings on a daily basis. Balances on these deposits then become subject to the cash withdrawal controls described above. As a result, businesses are unable to meet their operating expenses given their inability to withdraw cash from their bank accounts.

\section{Implications For Economic Behavior}

The policies of restricting cash in circulation, limiting conversion, and applying other distortionary measures have clearly been damaging for economic activity and have led to welfare losses. Below, we review the impact of these restrictions on economic activity, by type of distortion and by economic agents.

\section{a) Cash Shortages}

Households: As indicated above, cash shortages led to wide-spread wage and pension arrears throughout much of $2004 .{ }^{18}$ These shortages have also lead to a substantial decline in velocity of broad money by about 22 percent throughout the year, ${ }^{19}$ as customers hoarded the cash they managed to get, as a precautionary measure in an environment of ever-tightening cash limits, while accumulating deposits that were not liquid. Evidence of this - as well as of some individual consumers and small businesses resorting to barter transactions as a result of cash shortages-is reported in Figure A-6. Many view cash shortages also as a root cause of wage and pension arrears, as reported in Figure A-7. The fact that for a large number of employees salaries are directly deposited to their bank accounts further exacerbates the impact of problems accessing cash (Figure A-8).

Enterprises: The extensive restrictions on financial intermediation continue to contribute to the difficult business environment, and provide further opportunities and justifications for expanding the shadow economy and encouraging rent seeking. Because of cash shortages, enterprises were frequently unable to pay for their current expenditures on time. ${ }^{20}$ In addition to increasing the transaction cost for already existing enterprises, cash shortages are likely to serve as a major deterrent for the emergence of new small and medium enterprises, which-by virtue of their restricted access to finance-rely more heavily on the timeliness of current transactions. ${ }^{21}$ The restrictions on access to cash, combined with the mandatory daily deposit of cash receipts, are likely to force businesses to operate in the shadow economy as the only way to get cash sums. Finally, it is likely that cash restrictions are hurting enterprises through reduced employee productivity resulting from delays in wage (and pension) payments. A World Bank study of the cotton market, Guadagni et al. (2005), states that "one of the reasons of the exceptional yields of the 2004 campaign was the increased cash payment for harvesting" and as an incentive-enhancing measure proposes the introduction of a 10 percent cash payment for delivering cotton to the ginneries.

Financial intermediaries: Cash restrictions have resulted in an erosion of confidence in the banking system, as individuals and businesses have been unable to

\footnotetext{
${ }^{18}$ It is important to note that this took place while the government continued to build up deposits at the CBU.

${ }^{19}$ Velocity declined by additional 18 percent in 2005 .

20 This happened despite the government's giving civil service wage and pension payments a priority, along with wage payments to key state-owned enterprises.

${ }^{21}$ Securing enough cash to pay wages (by making frequent trips to banks) adds to administrative and labor costs, which private sector participants claim are sizable.
} 
access their deposit accounts, as a result of commercial banks' inability to access their correspondent accounts at the CBU. As a result, trust in the banking sector remains very low, undermining the financial intermediary role of banks. ${ }^{22}$ This has led banks-in their quest for new deposits - to offer high interest rates, which is likely to undermine their profitability and increase their risk profile. ${ }^{23}$

\section{b) Convertibility Problems}

Households: Currency convertibility for the households has tremendously improved since Uzbekistan's acceptance of Article VIII. Although there are some difficulties, as mentioned above, this segment of the population usually has access to foreign exchange through exchange bureaus. ${ }^{24}$ However, the major problem consumers face is limited access to sums-given the existing cash constraints-in order to buy foreign exchange. The reasons given to respondents for problems converting sums into dollars and visa versa are largely similar and frequently cite the lack of the opposite currency to make the exchange, computer problems, and limits on the amount that can be converted (Figures A-9 and A-10). ${ }^{25}$ As a result, many entrepreneurs resort to the services of the black market, with about 46 percent of them using the black market at least occasionally, while 11 percent deal with the black market exclusively (Figure A-11). Furthermore, convertibility restrictions are likely to limit consumers' ability to have a larger variety (and at times also better quality) of goods available for purchase.

Enterprises: Convertibility restrictions are aimed at limiting enterprises' ability to import some consumer goods. The authorities' reasoning behind these restrictions seems to be geared toward the protection of local industry, but indications are that the restrictions are tied with the authorities' targets for foreign reserve accumulation, protecting the latter against claims to import "unproductive" goods. While explicitly or implicitly protecting a few local producers from foreign competition, these restrictions will likely have adverse effects on a wide range of other producers and sectors in the economy through increasing the cost and reducing the availability of imported inputs. Coupled with an otherwise restrictive trade regime (with high tariff and non-tariff barriers in place), these protectionist measures are also likely to hurt export performance. ${ }^{26}$ Section IV below highlights an opposite impact of convertibility limits on domestic production and consumption.

Financial intermediaries: Limits on convertibility and on the ability of banks to sell foreign exchange through the interbank market has significantly slowed the establishment of an inter-bank foreign exchange market. If these restrictions continue to

\footnotetext{
22 While the ratio of broad money to GDP has rebounded to about 15 percent in 2005 from 10 percent in 2003, it is still one of the lowest among the Commonwealth of Independent States (CIS).

${ }_{23}$ Following the Presidential Decree No.147 of August 5, 2005, the CBU has announced that banks would be granted full access to their correspondent accounts and all legal restrictions on cash transactions would be abolished. This resulted in a significant improvement with cash availability, with no recent reports on wage and pension arrears and shortages of cash in exchange bureaus. However, the commercial banks' access to their correspondent accounts in CBU is not yet fully liberalized. In many instances, banks still rely on cash foreign exchange operations in exchange bureaus (as opposed to their accounts at the CBU) for cash sums.

${ }^{24}$ During 2005, exchange bureaus purchased $\$ 448$ million from and sold $\$ 1,014$ million to households.

25 The average limit of the amount to be exchanged from dollars into sums was quoted by respondents to be $\$ 224$, while that for the amount to be exchanged from sums into dollars was $\$ 300$.

26 See Tokarick (2006), who estimates export loses as a result of import restrictions in a sample of developing countries.
} 
remain in place, they will further undermine confidence in the banking sector, reducing the ability of banks to effectively service their customers, and delaying economic recovery. ${ }^{27}$

\section{c) Other Distortions}

Households: The role of banks in tax collection and financial oversight, against principles of confidentiality and secrecy, discourages households from using banking services. With respect to plastic cards - which in many countries are an important part of the payment infrastructure-success in Uzbekistan will depend on the timing of their introduction and on consumers' ability to use them voluntarily. If introduced prematurely, consumers would have great difficulty paying for routine expenses.

Enterprises: Instead of discouraging shadow market activity, the numerous market distortions have encouraged legitimate businesses to engage in shadow activities. These distorted practices have placed an onerous and unnecessary burden on businesses, and have contributed to an increase in transaction costs. Most retail establishments-particularly non-state-owned retail establishments-are not equipped to accept payments via debit cards, and therefore would be deprived of a large chunk of their daily legitimate business should the use of these cards be made mandatory.

Financial intermediaries: The observed distortions affect the role of financial intermediaries in many ways, mainly by weakening confidence in the banking system. This works through the following channels. First, the distinction between cash and noncash payments sends a strong message that cash and non-cash payments are not substitutes, which undermines confidence in the sum as a unit of exchange. Second, the continuing surrender requirement in the presence of comfortable foreign exchange reserves at the CBU sends a mixed signal about the true intentions of the authorities in terms of allowing full convertibility, and thus reduces the demand for sums as a store of value. Finally, tax and financial control functions performed by banks discourages individuals and businesses from dealing with the sector. ${ }^{28}$

\section{Implications for the Uzbek Economy}

Based on the findings of the model described in the Appendix, this section outlines the likely implications of cash and convertibility restrictions-as well as their abolishment-on aggregate output, consumption behavior, trade, and welfare. The model used in the paper builds on a cash-in-advance framework (originated by Clower, 1967), but introduces additional elements to reflect the financial sector restrictions discussed above. ${ }^{29}$ While cash-in-advance constraints have been commonly used in macroeconomic modeling to justify the role of money, in this model the cash-inadvance framework is also used to reflect the government's desire to control cash in circulation through (i) the CBU's control of banks' access to their correspondent

\footnotetext{
27 Evidence of low confidence in the banking system can be found in Table A-2, where lack of trust and inability to withdraw cash were both ranked highly on the list of the most pressing concerns expressed by the respondents.

${ }^{28}$ Banks are required by law to submit to tax and law enforcement authorities information about their customers' bank accounts and transactions. Taxes can then be levied on these transactions and taken out of the account, forcing banks to perform fiscal functions for the government.

29 The paper introduces a convertibility constraint, which applies to imports of both consumption and capital goods. This latter element follows Stockman (1981), who allows the cash-in-advance constraint to also apply to purchases/accumulation of capital goods.
} 
accounts, (ii) the inability of individuals to withdraw cash from their deposits to finance current expenditures, and (iii) the wage and pension arrears generated as a result of cash shortages. The role of cash and cash-in-advance constraints in this setting are also reinforced by the limited access to consumer credit in Uzbekistan for current transactions.

The results of the analytical model would only reflect the direct impacts of the observed restrictions on economic activity. While it is likely that cash restrictions (which are reflected in wage and pension arrears) would reduce the incentives to work and thus labor productivity, capturing this indirect effect would have unduly complicated the model. Not modeled in this framework is the indirect confidence-reducing impact of these restrictions, that would affect financial intermediation, cost and availability of finance, and eventually output.

\section{a) The Model}

This section contains the analytical foundations behind economic implications of cash and convertibility restrictions and proposed policy prescriptions. It is based on a representative agent model that aims to capture the distortions present in the Uzbek economy. The intention is to obtain the responses of key variables of interest (e.g., aggregate output, consumption, and trade) with respect to tightness of the cash-inadvance and convertibility constraints. The details of the derivations (of the steady-state solutions of the model) are contained in Appendix II.

A representative agent maximizes her utility function, ${ }^{30}$

$$
\int_{0}^{\infty} u(h, g) \cdot e^{-\rho t} d t
$$

subject to the following constraints:

$$
\begin{array}{ll}
a=c+e m^{*}+k+d & \text { Definition of assets } \\
\dot{a}=f(k)-h-e g-\pi c+r d & \text { Asset accumulation constraint } \\
c \geq \alpha(h+e g) & \text { Cash-in-advance constraint } \\
e m^{*} \geq \beta(e g+\dot{k}) & \text { Convertibility constraint } \\
c+d=m \text { where } \dot{m}=\mu & \text { Money market condition }
\end{array}
$$

where $h$ and $g$ are the consumption of domestically produced and imported goods, respectively; $m^{*}$ is the amount of foreign exchange holdings; $k$ stands for capital goods (which are assumed to be imported); $f(\cdot)$ a decreasing-returns-to-scale production function; $\pi$ is the rate of inflation; $e$ is the exchange rate which is assumed fixed

30 The time subscripts are dropped for expositional simplicity. 
throughout, ${ }^{31} c$ is cash in circulation, $d$ stands for deposits, $m$ is the money supply (where $m(0)=m_{0}$, which jointly with $\dot{m}=\mu$ indicate that the path of money supply is fully specified), and $r$ is the real rate of interest. We assume - for simplicity and without loss of generality — that capital does not depreciate. Here, parameters $\alpha$ and $\beta$ can be interpreted as the length of time money must be held to finance consumption and secure conversion, respectively (see Feenstra, 1985). Thus, higher values for $\alpha$ and $\beta$ mean stricter cash and convertibility restrictions. Thus, the government controls the rate of money growth $\mu$ (by issuing domestic credit) as well as $\alpha$ and $\beta$ (by creating wage/pension arrears and hurdles for conversion, respectively).

Assuming that both (4) and (5) are binding, we replace them with equalities. Substituting those into (2) yields:

$$
\dot{k}=\frac{1}{\beta}(a-\alpha h-e g(\alpha+\beta)-k-d)
$$

Also, substituting (4) into (3) yields:

$$
\dot{a}=f(k)-h(1+\alpha \pi)-e g(1+\alpha \pi)+r d
$$

The corresponding first order conditions for the maximization of (1) with respect to (7) and (8) are as follows: ${ }^{32}$

$$
\begin{aligned}
& u_{h}-\frac{\alpha}{\beta} \lambda-(1+\alpha \pi) \theta=0 \\
& u_{g}-\frac{e(\alpha+\beta)}{\beta} \lambda-e(1+\alpha \pi) \theta=0
\end{aligned}
$$

31 Given the policymakers' drive for reserve accumulation and competitiveness concerns, on the one hand, and the ability to control the demand for imports through altering conversion restrictions (and through that controlling any potential pressure on the exchange rate), on the other hand, the assumption of fixed exchange rate is not too implausible in this set-up.

32 The underlying Hamiltonian is:

$$
\begin{aligned}
H\langle h, g, d, \lambda, \theta \mid a, k\rangle=u(h, g)+\lambda \frac{1}{\beta}(a-\alpha h & -(\alpha+\beta) e g-k-d) \\
+ & \theta(f(k)-h(1+\alpha \pi)-e g(1+\alpha \pi)+r d)
\end{aligned}
$$

where $\lambda$ and $\theta$ are the shadow values for capital and assets, respectively. Strictly speaking, if both conditions (4) and (5) are binding, because $c$ and $m$ have pre-determined paths and capital accumulation is restricted by equation $5, d$ is no longer a choice variable. Instead it acts as a residual between money supply and cash in circulation. In practice, this relationship is ensured by the authorities in Uzbekistan through the cash surrender requirements described above: by collecting cash from all retailers at the end of the day, on the next day the authorities inject back the amount of cash which is consistent with their path for cash in circulation, and force the agents to keep their funds in the form of deposits. 


$$
\begin{aligned}
& -\frac{\lambda}{\beta}+r \theta=0 \\
& \dot{\lambda}=\rho \lambda-\frac{\partial H}{\partial k}=\rho \lambda+\frac{\lambda}{\beta}-\theta \cdot f^{\prime}(k) \\
& \dot{\theta}=\rho \theta-\frac{\partial H}{\partial a}=\rho \theta-\frac{\lambda}{\beta}
\end{aligned}
$$

The steady state solution drawn in (a, k) space would be a saddle path (denoted 1 below).

Figure 1. The Steady State Path

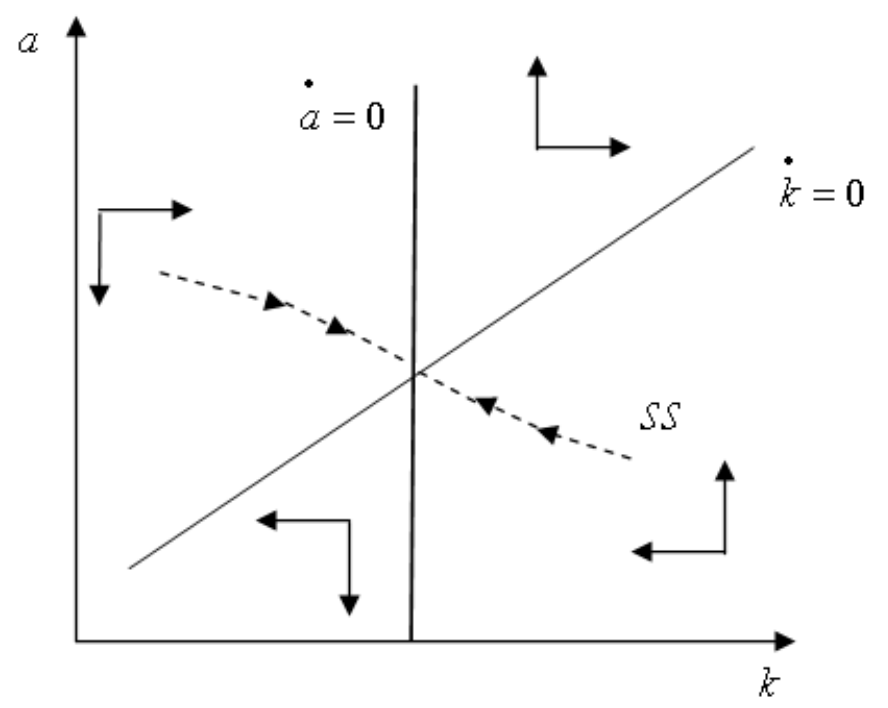

Without going though the derivation of the steady state relationships between key variables key variables (which is discussed in Appendix II), we move on to the main results stemming from the model.

\section{b) Findings}

The findings of the analysis can be summarized as follows. First of all, the optimal steady-state capital stock appears to be a decreasing function of convertibility restrictions. Thus, the steady-state capital stock, investment, and output would likely increase if convertibility requirements are relaxed. Availability of more foreign currency for conversion would result in more imports of capital and intermediate goods and, subsequently, more investment and output.

Second, tightening of cash restrictions has a dampening effect on domestic consumption. However, the impact of convertibility constraints on domestic 
consumption is ambiguous. While the restrictions on convertibility (and, therefore, on imports of foreign goods) have a direct impact of encouraging domestic consumption (since domestic and foreign goods are assumed to be substitutes), the indirect effect through production will have the opposite effect on domestic consumption. The net effect will depend on the parameters of the production function and the degree of substitutability between domestic and imported consumption.

Third, the impact of both types of restrictions on imported consumption goods is negative.

Fourth, the convertibility restrictions encourage deposit accumulation (since fewer dollars are made available to finance imports, and therefore fewer sums would be exchanged ceteris paribus). In contrast, the limits on cash are likely to reduce the amount of deposits. This can be seen as a result of consumers being forced to hold more cash (and less money in deposits) in response to tightening requirements. ${ }^{33}$ This constitutes a clear wedge between the authorities' policy intentions (of reducing cash in circulation) and the actual outcome (of increased cash holdings) as a result of tighter cash restrictions. This is reflected in the growth of the share of cash (in broad money) held outside of banks, which has increased substantially in recent years. ${ }^{34}$

Fifth, cash shortages have an unambiguous negative impact on consumers' utility/welfare, through the reduction of both components of consumption. While as mentioned above, the impact of convertibility on domestic consumption is ambiguous, the (utility obtained from the) reduction in consumption of foreign goods is larger than any potential increase in (the utility obtained from) domestic consumption. Hence, the unambiguous welfare-reducing implication of convertibility limits.

Finally, despite the dampening impact of both types of restrictions on imports, they have different impacts on the current account. Since there is no (direct) impact from cash restrictions on output (and therefore exports) in the model, the impact on the current account would be through the impact on imports. The limits on convertibility, however, have an impact on aggregate production and exports, in addition to reducing imports, and therefore have an ambiguous impact on the current account.

\section{Policy Prescriptions}

To encourage financial sector reforms, and through that enhance the economy's growth potential, the authorities in Uzbekistan would be well advised to revise their views and policies, specifically pertaining to the relationships between (i) inflation and cash in circulation, (ii) restrictions on cash and shadow economic activity, and (iii) import (including convertibility) restrictions and aggregate welfare.

Regarding inflation control, the CBU should target appropriate growth in money supply, while allowing the market to determine the shares of cash and deposits. As demonstrated by the simple modeling exercise above, eliminating the cash restrictions is unambiguously welfare-enhancing and the authorities should take measures to reduce cash shortages and the resulting wage and pension arrears. ${ }^{35}$

\footnotetext{
${ }^{33}$ If, as suggested above, tighter restrictions of cash and convertibility are interpreted as the length of time money must be held to finance consumption and secure conversion, it is intuitive that in response to tightening cash limits, consumers will hold more cash and less deposits.

34 This ratio has increased from 34 to 46 percent between 2002 and 2005.

35 A complete liberalization of cash restrictions may initially lead to an increase in cash holdings as agents continue to accumulate precautionary cash balances (while unsure about the duration of the CBU's
} 
On curbing illegal activity, instead of relying on administrative measures, such as restricting cash in circulation (which are likely to be counterproductive), the authorities should focus on addressing the incentives for participation in the shadow economy. The requirement for retail establishments to deposit all cash proceeds on a daily basis should be abolished as one of the first steps toward removing tax collection responsibilities from banks.

With regard to the elimination of cash and non-cash distinctions, to the extent that the purpose of these restrictions is to prevent money laundering, the authorities should follow the practice of other countries by replacing these restrictions with a requirement for banks to report all cash transactions above a certain size. This distinction between cash and non-cash payments poses an unnecessary burden for businesses and increases the transaction costs of doing business in Uzbekistan.

The authorities have recently issues decrees aiming to eliminate all forms of cash restrictions and to phase out the elimination of the surrender requirements. (The list of laws and regulations issued in the past that contained cash and foreign exchange restrictions of different nature is reported in Appendix III). If these restrictions were credibly eliminated, this could be an important step toward the development of a modern and competitive financial system. If, however, these and other restrictions remain in place, or changes are introduced in a less-than-fully-credible manner, ${ }^{36}$ the financial sector will continue to be marginalized and would have little to offer in the way of financial intermediation and growth opportunities for the private sector.

\section{References}

Berengaut, Julian and Katrin Elborgh-Woytek (2005). 'Who is Still Haunted by the Specter of Communism? Explaining Relative Output Contractions Under Transition,' International Monetary Fund Working Paper 68.

Clower, Robert (1967) 'A Reconsideration of Microeconomic Foundations of Monetary Theory,' Western Economic Journal, 16, 73-85.

Economist Intelligence Unit (2006) Democracy Index, available at http://www.economist.com/media/pdf/DEMOCRACY TABLE 2007 v3.pdf

Feenstra, Robert (1985) 'Anticipated Devaluations, Currency Flight, and Direct Trade Controls in a Monetary Economy,' American Economic Review, 75, 386-401.

Guadagni, Maurizio, Martin Raiser, Anna Crole-Rees, and Dilshod Khidirov (2005) 'Cotton Taxation in Uzbekistan: Opportunities for Reform,' ECSSD Working Paper 41, World Bank.

International Financial Corporation (2004) Uzbekistan: Business Environment Survey.

Pomfret, Richard (2003) 'Economic Performance in Central Asia since 1991: Macro and Micro Evidence,' Comparative Economic Studies 45, 4, 442-465.

Ranaweere, Thilak (2003). 'Market Disequilibria and Inflation in Uzbekistan, 1994-2000,' World Bank Policy Research Working Paper 3144.

commitment to eliminate cash shortages), leading to an initial decline in velocity. However, once confidence is fully restored, agents will reduce their cash holdings to more normal levels.

${ }^{36}$ Credibility of abolition of cash restrictions is important in this context, because if (or to the extent that) these measures are perceived to be temporary, they could lead to bank runs as consumers attempt to use the temporary window of opportunity to cash their deposits. 
Rosenberg, Christoph B. and Maarten de Zeeuw (2000) 'Welfare Effects of Uzbekistan's Foreign Exchange Regime,' International Monetary Fund Working Paper 61.

Stockman, Alan, 1981. "Anticipated Devaluation in the Capital Stock in a Cash-In-Advance Economy," Journal of Monetary Economics, 8, 387-393.

Taube, Gunther and Jeromin Zettelmeyer (1998) 'Output Decline and Recovery in Uzbekistan: Past Performance and Future Prospects,' International Monetary Fund Working Paper 132.

Transparency International (2006) Corruption Perception Index, available through http://www.transparency.org/publications/gcr/download gcr.

Tokarick, Stephen, (2006) 'Does Import Protection Discourage Exports?', International Monetary Fund Working Paper 20.

Zettelmeyer, Jeromin, (1998) 'The Uzbek Growth Puzzle,' International Monetary Fund Working Paper 133. 


\section{Appendix I: Survey Description and Outcomes}

Within the framework of the World Bank's and IMF's surveillance of economic policies in Uzbekistan, a population survey was conducted in summer 2005 to better assess the extent and implications of financial sector distortions in Uzbekistan. This Appendix contains a summary of some relevant survey outcomes.

Distribution of respondents by city and sector are reported in Table A-1 below:

Table A-1. Distribution of Survey Respondents

\begin{tabular}{|c|c|c|c|c|c|}
\hline \multirow[b]{2}{*}{$\underline{\text { Sectors }}$} & \multirow[b]{2}{*}{ Percent } & \multicolumn{4}{|c|}{ Number of respondents } \\
\hline & & Tashkent & Fergana & Bukhara & Karshi \\
\hline $\begin{array}{l}\text { Employed in the budget sector } \\
\text { (teachers, doctors, etc.) }\end{array}$ & 30 & 90 & 45 & 45 & 45 \\
\hline Employed at state enterprises & 20 & 60 & 30 & 30 & 30 \\
\hline $\begin{array}{l}\text { Employed in the banking sector } \\
\text { (banks, etc.) }\end{array}$ & 10 & 30 & 15 & 15 & 15 \\
\hline Private entrepreneurs & 30 & 90 & 45 & 45 & 45 \\
\hline $\begin{array}{l}\text { Receiving social benefits (pensions, } \\
\text { allowances, stipends, etc.) }\end{array}$ & 10 & 30 & 15 & 15 & 15 \\
\hline TOTAL & 100 & 300 & 150 & 150 & 150 \\
\hline
\end{tabular}

The survey was conducted through personal interviews using a standardized questionnaire. Interviews were conducted in the language preferred by the respondent (Uzbek or Russian). After completion of the survey, 15 percent of all the interviews were checked by the method of second visits and confirming the main parameters of the interviewed households. Select answers to survey questions are summarized below.

Figure A-1: Frequency with which cash can be retrieved from bank accountsregardless of the amount

(percent of respondents with bank account, by city)

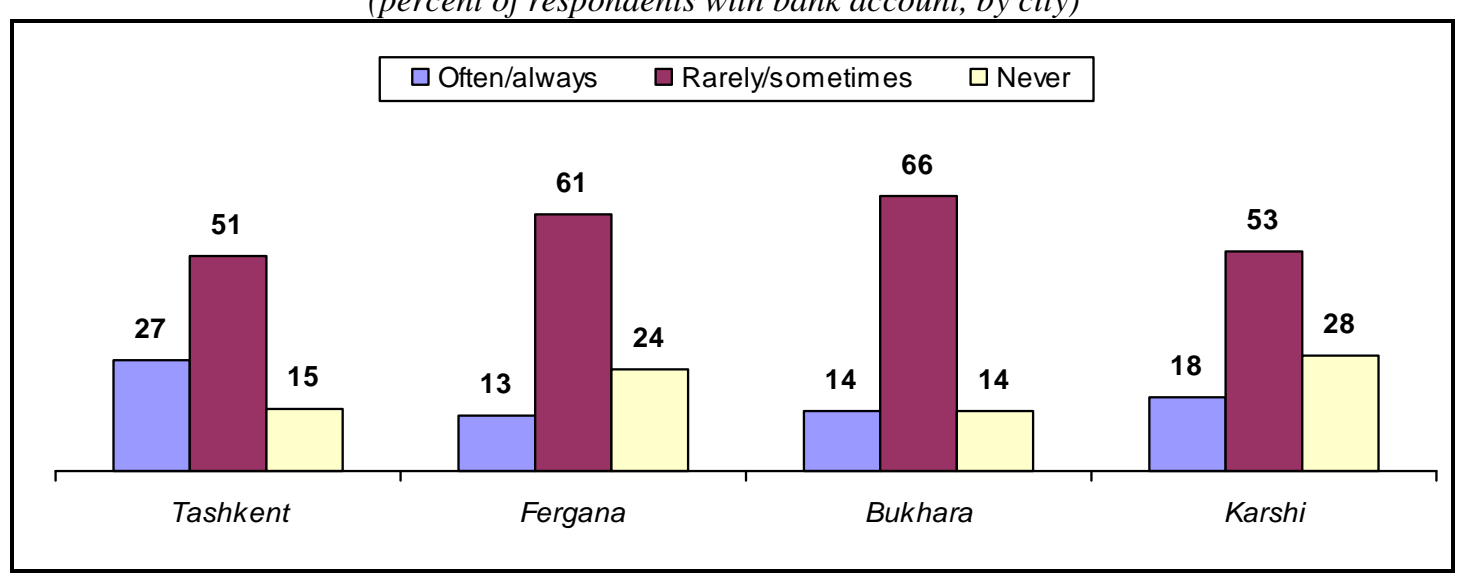

Figure A-2: The amount of cash that can be retrieved from a bank account when needed (percent of respondents with bank accounts, by city) 


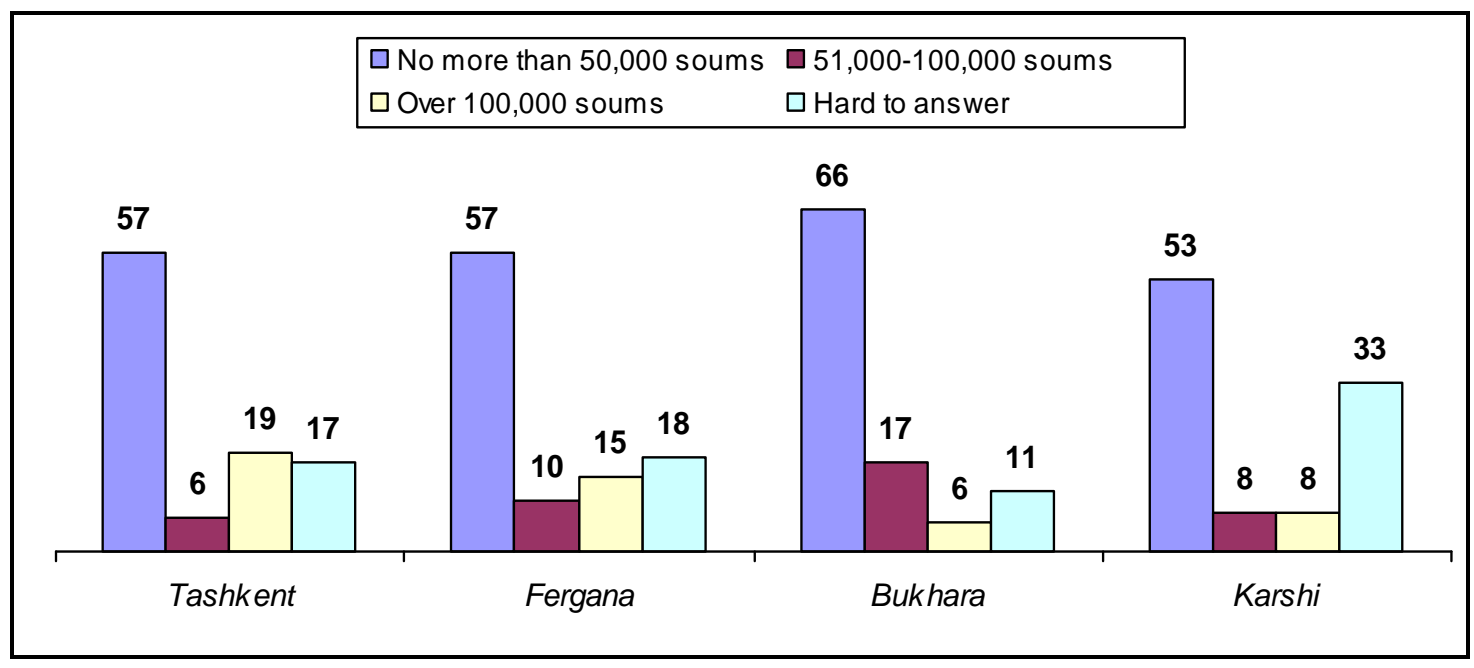

Figure A-3: Percentage of respondents paying premium on non-cash payments (percent of total number of respondents, by city)

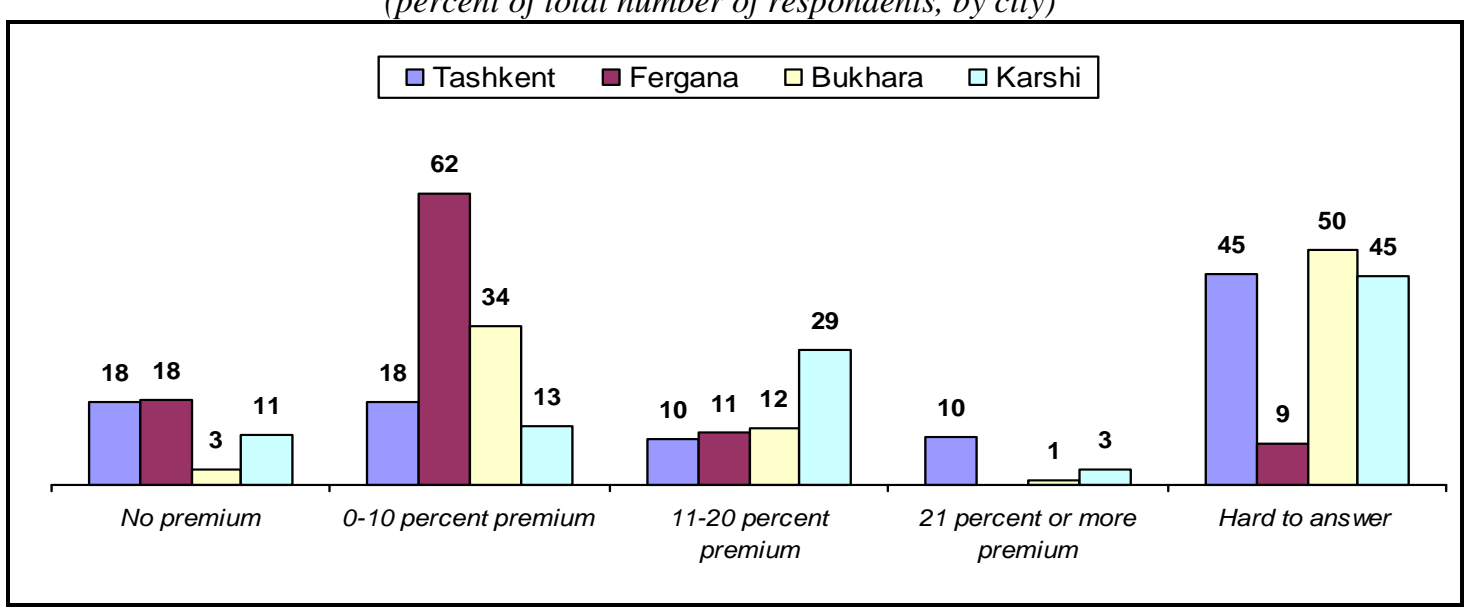

Figure A-4: How many times does it take to exchange dollars for sums during the past 30 dates (percent of total number of respondents who attempted to exchange dollars during that period)

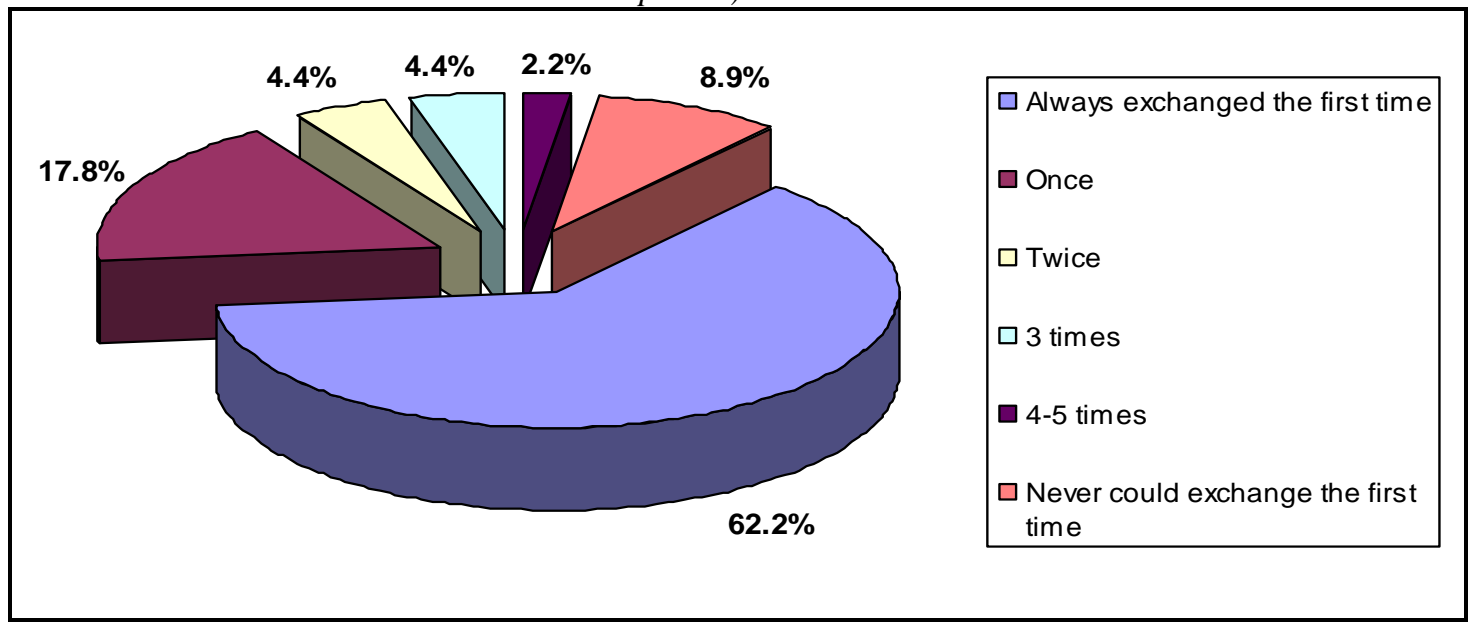

Figure A-5: Average number of people standing in line to in front of exchange bureaus,by city. 
Edward Gemayel and David Grigorian, Distortionary Policies in Uzbekistan

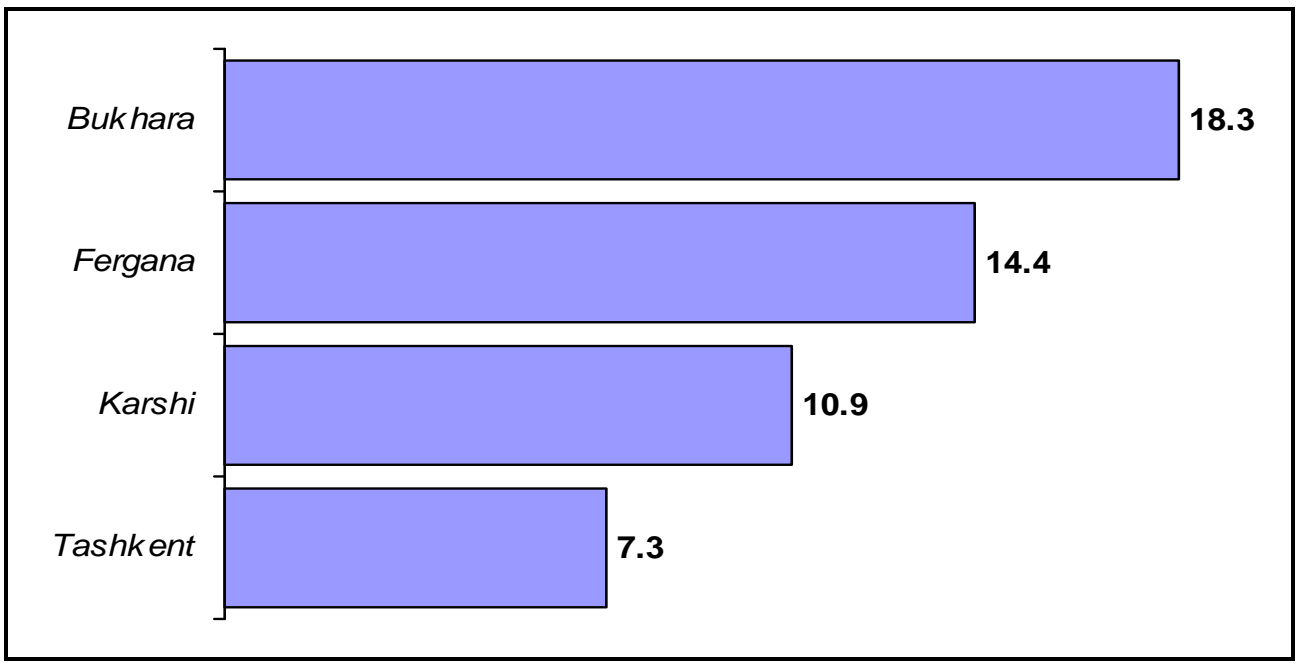

Figure A-6: Frequency of using different strategies to cope with the difficulty of accessing cash sums (percent of the total number of respondents)

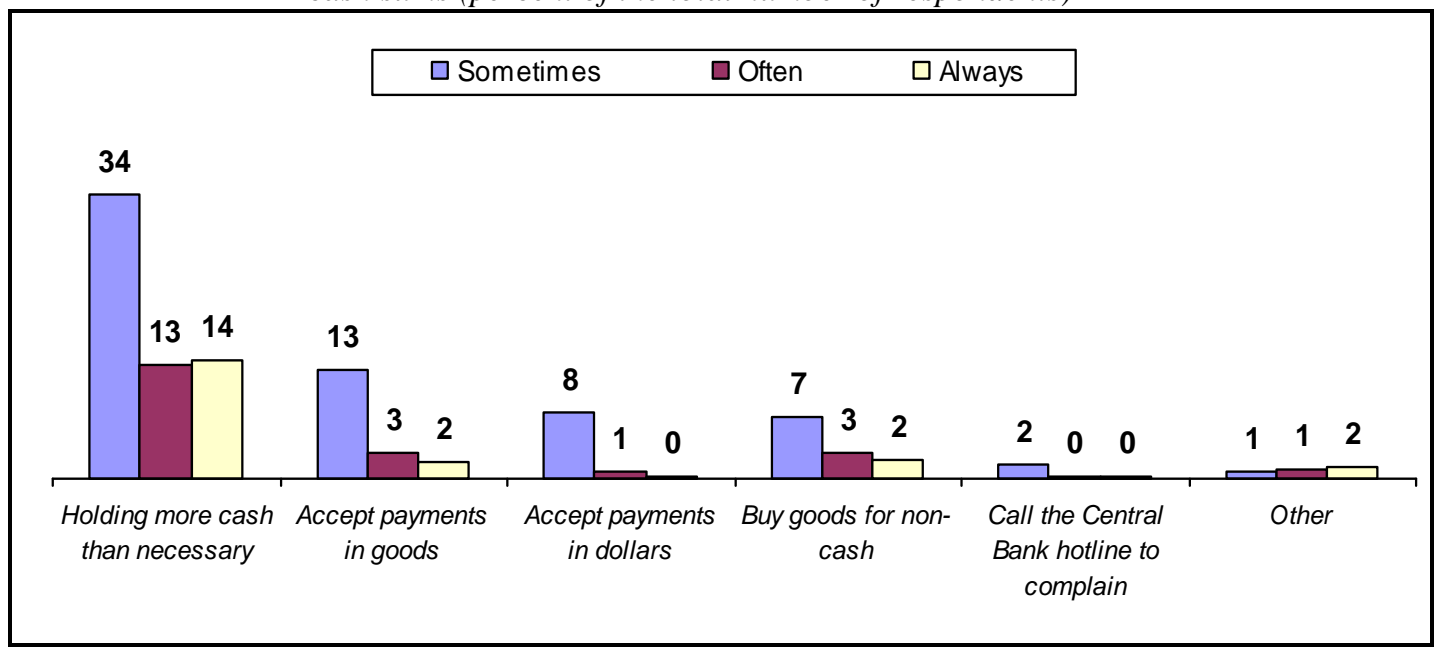

Available online at http://eaces.liuc.it 
Figure A-7: Arrears in wages and other payments due to cash unavailability (percent of total number of respondents, by city)

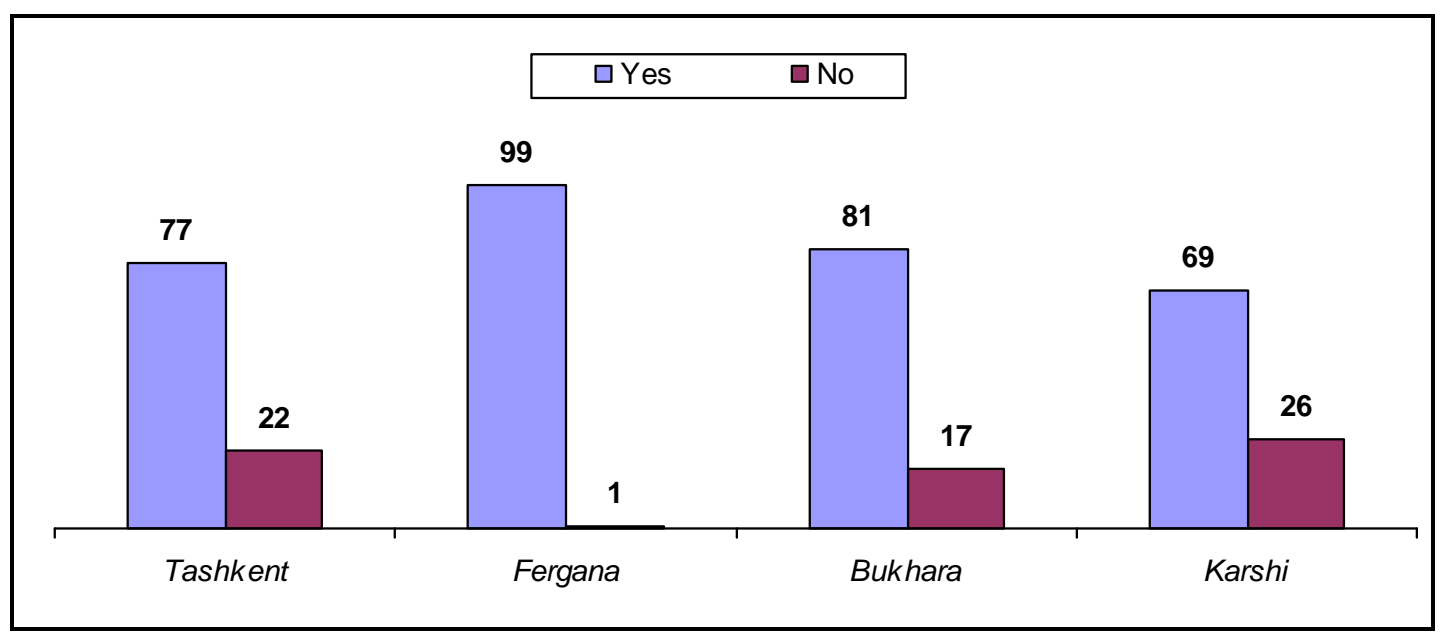

Figure A-8: Percentage of employed whose salaries are paid into a bank account (by cities)

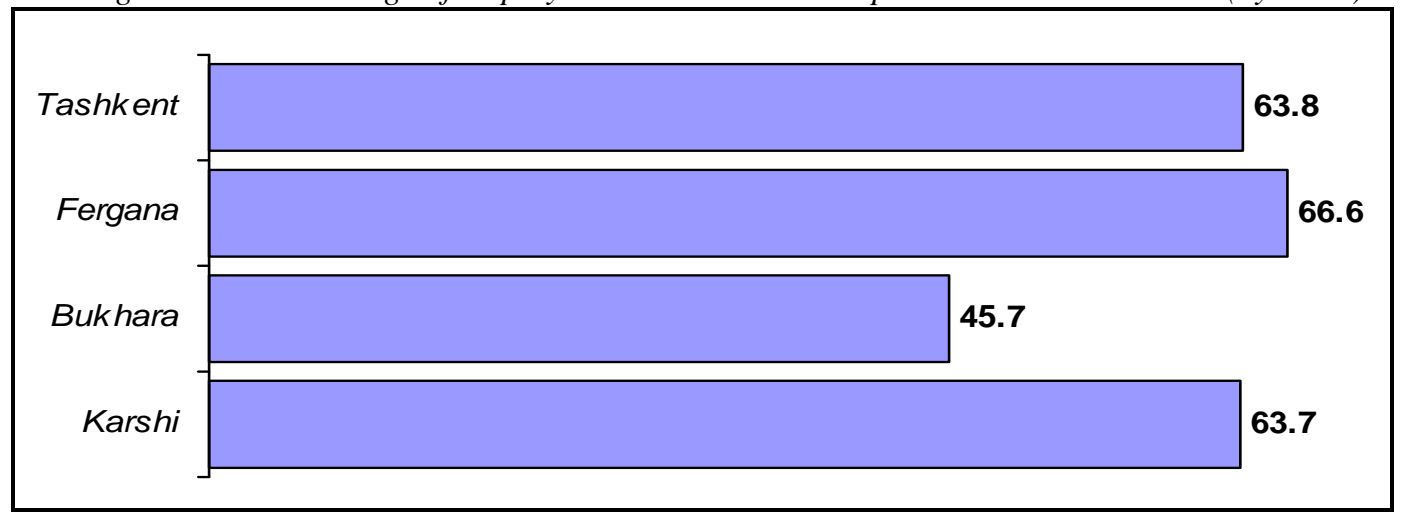

Figure A-9A: Reasons for refusals to exchange dollars into sums (percent of total number of respondents who attempted to exchange dollars during that period)

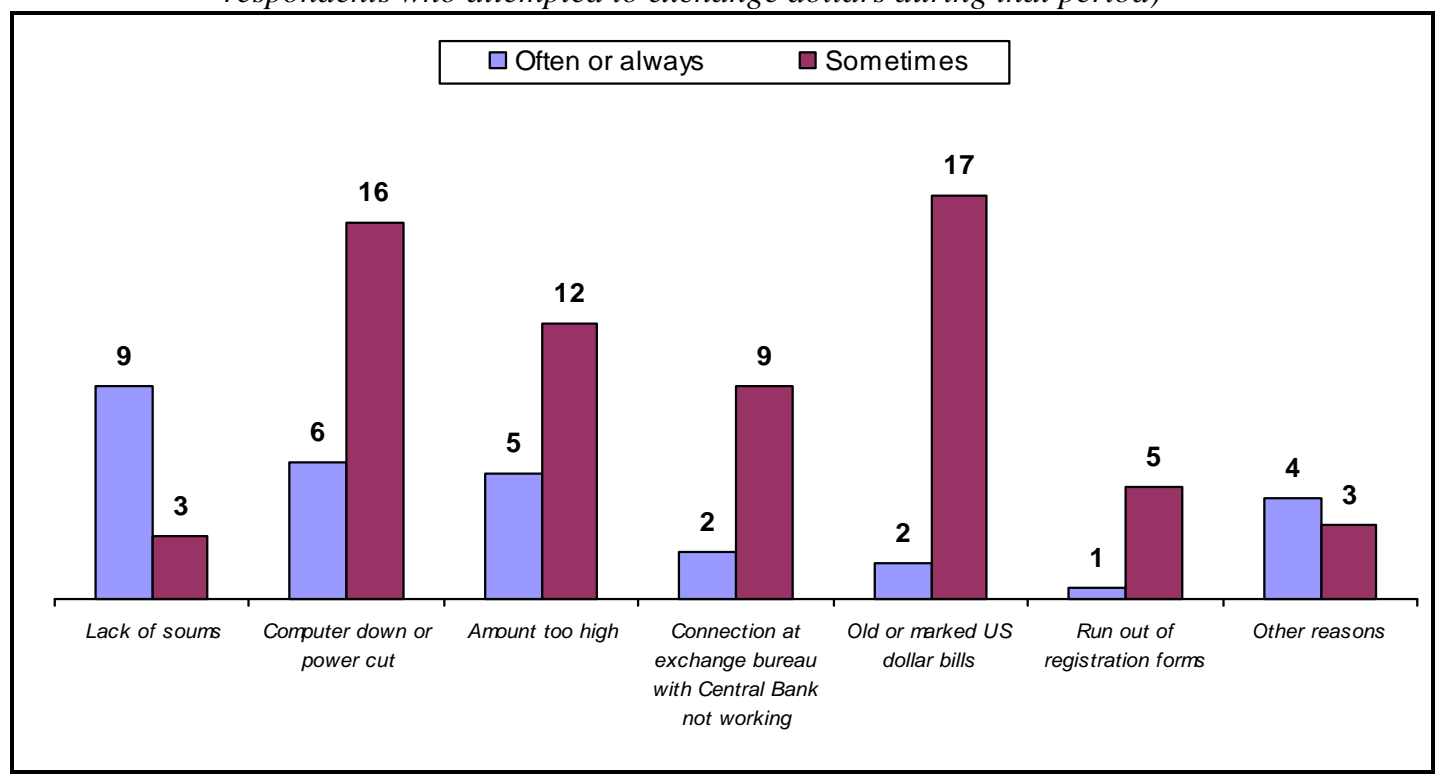

Available online at http://eaces.liuc.it 
Edward Gemayel and David Grigorian, Distortionary Policies in Uzbekistan

Figure A-9B:Reasons for refusals to exchange sums into dollars (percent of the number of respondents having ever bought dollars, in the four cities on the whole)

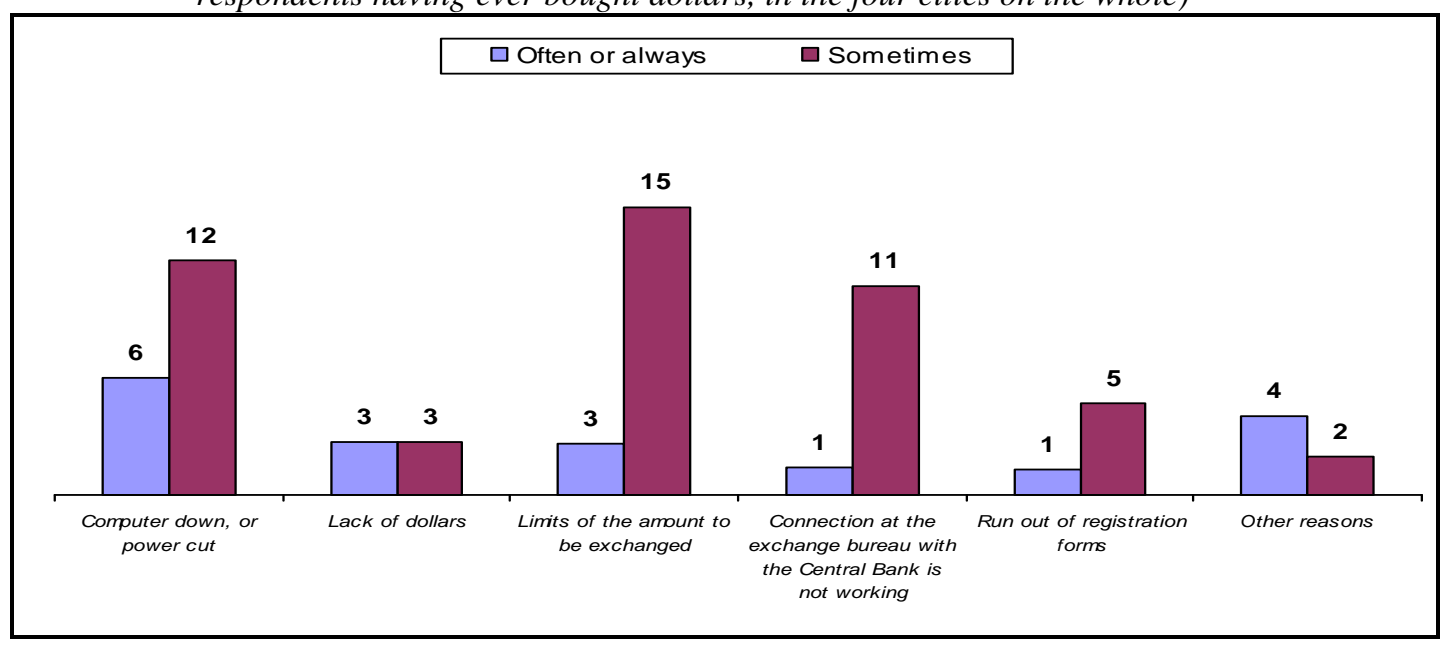

Figure A-10: Frequency of exchanging U.S. dollars by private entrepreneurs at the black market (percent of total number of private entrepreneurs who have exchanged dollars for sums during the previous 30 days)

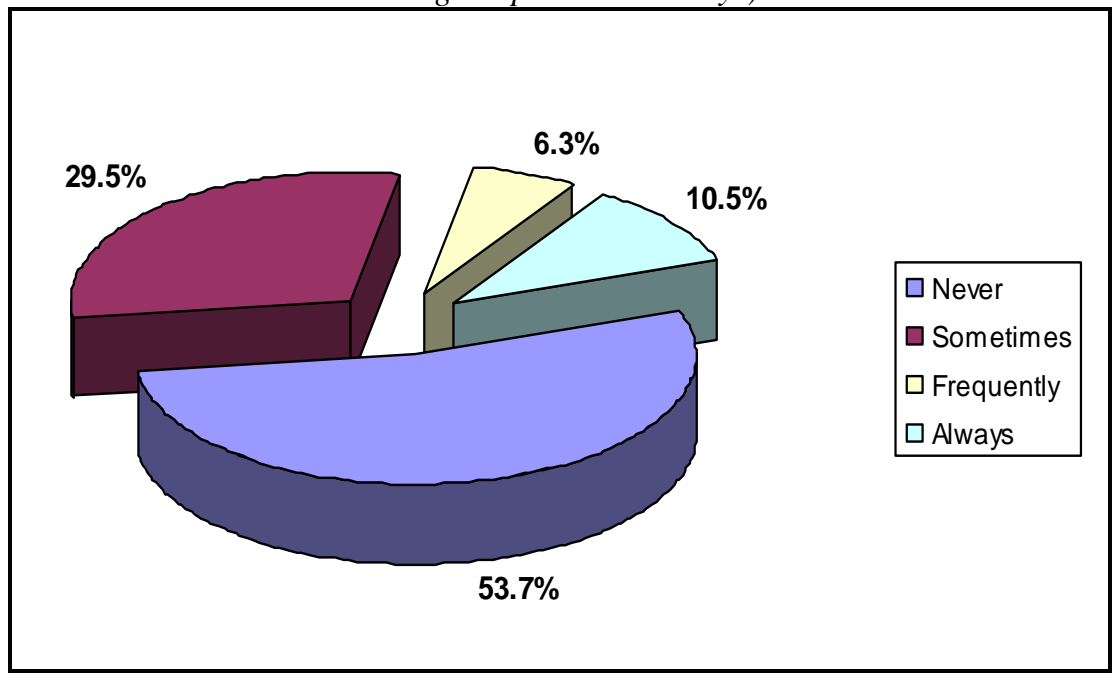

Table A-2. Issues of Biggest Concern

(percent of total number of respondents by sector)

\begin{tabular}{llllll}
\hline Description of the Issue & $\begin{array}{l}\text { Budget } \\
\text { sector } \\
\text { employees }\end{array}$ & $\begin{array}{l}\text { State } \\
\text { enterprise } \\
\text { employees }\end{array}$ & $\begin{array}{l}\text { Banking } \\
\text { sector } \\
\text { employees }\end{array}$ & $\begin{array}{l}\text { Private } \\
\text { business } \\
\text { owners }\end{array}$ & $\begin{array}{l}\text { Social } \\
\text { benefit } \\
\text { recipients }\end{array}$ \\
\hline $\begin{array}{l}\text { My wages (pension, stipend, etc.) are being } \\
\text { paid with delay }\end{array}$ & 46.7 & 52.7 & 1.3 & 11.6 & 50.7 \\
$\begin{array}{l}\text { I don't trust the banks and hence need to } \\
\text { keep much more cash than I want }\end{array}$ & 18.7 & 17.3 & 10.7 & 25.8 & 16.0 \\
$\begin{array}{l}\text { I cannot retrieve as much cash as I need } \\
\text { from my bank account }\end{array}$ & 5.3 & 6.7 & 26.7 & 28.9 & 1.3 \\
$\begin{array}{l}\text { Small size of my wages (pension, stipend, } \\
\text { etc.) lack of money/savings }\end{array}$ & 10.7 & 4.0 & 9.3 & 4.9 & 9.3 \\
$\begin{array}{l}\text { I cannot exchange as many sums into } \\
\text { dollars (or dollars into sums) as I need }\end{array}$ & 2.7 & 2.7 & 5.3 & 7.6 & 2.7 \\
$\begin{array}{l}\text { Other } \\
\text { Difficult to answer }\end{array}$ & 6.7 & 6.0 & 5.3 & 8.9 & 4.0 \\
\hline
\end{tabular}




\section{Appendix II - Derivations of the Model}

This Appendix finalizes the derivation of the model outlined in Section X above. We would begin here by the steady-state relationships of key indicators.

In a steady-state, $\dot{\lambda}=0$ and $\dot{\theta}=0$ resulting in (12) and (13) transforming into

$$
\lambda\left(\rho+\frac{1}{\beta}\right)=\theta \cdot f^{\prime}(k)
$$

and

$$
\rho \beta \theta=\lambda \text {. }
$$

After substituting (15) into (14):

$$
f^{\prime}(k)=\rho(1+\rho \beta) \text {. }
$$

It follows from (A-15) and (11) that $\rho=r$, which suggests that in an equilibrium, the real interest rate will be equal to the intertemporal rate of discount. As expected, from (A-16), because $f^{\prime \prime}(k)<0$, the optimal capital stock, $k^{*}$, will be a decreasing function of convertibility restrictions, $\beta$. Thus, the steady-state capital stock, as well as the output, would increase if convertibility requirements are relaxed.

To determine the impact of cash and convertibility restrictions on consumption of domestic and foreign goods, we solve the model for the steady-state values of $h$ and $g$. Substituting (A-15) into (9) yields:

$$
u_{h}=\theta(1+\alpha \rho+\alpha \pi)
$$

while substituting it into (10) yields:

$$
\begin{aligned}
& u_{g}=e(\alpha+\beta) \rho \theta+e(1+\alpha \pi) \theta=e \theta(1+\alpha \rho+\beta \rho+\alpha \pi) \\
& \frac{u_{h}}{u_{g}}=\frac{(1+\alpha \rho+\alpha \pi)}{e(1+\alpha \rho+\beta \rho+\alpha \pi)} .
\end{aligned}
$$

Assuming a Cobb-Douglas utility function of the form $u(h, g)=h^{\sigma} g^{\sigma}$ (with $\left.\sigma<1\right)$ yields a simplified relationship between domestic and imported consumption goods:

$$
h=\frac{(1+\alpha \rho+\alpha \pi+\beta \rho)}{(1+\alpha \rho+\alpha \pi)} \cdot e g
$$

For the steady-state (i.e., when $\dot{k}=0$ and $\dot{a}=0$ ), (7) and (8) transform into:

$$
a^{*}=\alpha h^{*}+e g^{*}(\alpha+\beta)+k^{*}+d^{*}
$$

and

$$
f\left(k^{*}\right)=(1+\alpha \pi)\left(h^{*}+e g^{*}\right)-r d^{*}
$$


From (4) and (6) it follows that:

$$
\alpha\left(h^{*}+e g^{*}\right)+d^{*}=m \text {. }
$$

From (A-21) and (A-24), it follows that:

$$
a^{*}=\beta e g^{*}+k^{*}+m
$$

while from (A-21) and (A-22) it follows that:

$$
f\left(k^{*}\right)-r k^{*}+r a=2 e g^{*}(1+r(\alpha+\beta)+\alpha \pi) .
$$

Substituting (A-24) into (A-25) yields the expression for the equilibrium level of imported consumption goods:

$$
e g^{*}=\frac{f\left(k^{*}\right)+m}{2(1+r(\alpha+\beta)+\alpha \pi)-\beta r}
$$

Consequently, the consumption of domestically produced goods could be obtained by using (A-26) and (A-20):

$$
h^{*}=\frac{f\left(k^{*}\right)+m}{2(1+r(\alpha+\beta)+\alpha \pi)-\beta r} \frac{(1+\alpha \rho+\alpha \pi+\beta \rho)}{(1+\alpha \rho+\alpha \pi)}
$$

The only remaining endogenous variable, bank deposits, could then be obtained from (A-23), (A-26) and (A-27) as follows:

$$
d^{*}=m-\frac{f\left(k^{*}\right)+m}{2(1+r(\alpha+\beta)+\alpha \pi)-\beta r}\left(1+\frac{(1+\alpha \rho+\alpha \pi+\beta \rho)}{(1+\alpha \rho+\alpha \pi)}\right)
$$

We can now evaluate the following derivatives, which describe the changes in economic behavior in response to cash and convertibility restrictions in the model:

$$
\frac{\partial h^{*}}{\partial \alpha} ; \frac{\partial h^{*}}{\partial \beta} ; \frac{\partial\left(e g^{*}\right)}{\partial \alpha} ; \frac{\partial\left(e g^{*}\right)}{\partial \beta} ; \frac{\partial d^{*}}{\partial \alpha} ; \text { and } \frac{\partial d^{*}}{\partial \beta} \text {. }
$$

While it is relatively easy to see that the impact of both restrictions on imported consumption goods is negative, that is:

$$
\frac{\partial\left(e g^{*}\right)}{\partial \alpha}<0 ; \text { and } \frac{\partial\left(e g^{*}\right)}{\partial \beta}<0
$$

the derivatives of steady-state consumption of domestic goods with respect to tightness of cash and convertibility constraints can be shown to have the following signs:

$$
\frac{\partial h^{*}}{\partial \alpha}<0, \text { while } \frac{\partial h^{*}}{\partial \beta}><0
$$


It follows from the first inequality that the impact of cash restrictions have a dampening effect on domestic consumption. However, the impact of convertibility constraints is ambiguous. While the restrictions on convertibility (and therefore on imports of foreign goods) will have the direct impact of encouraging domestic consumption (since domestic and foreign goods are substitutes), the indirect effect through production will have the opposite effect on domestic consumption. The net effect will depend on the parameters of the production function and the degree of substitutability between domestic and imported consumption.

Regarding the impact of restrictions on bank deposits, the results are quite intuitive as well:

$$
\frac{\partial d^{*}}{\partial \alpha}<0 \text { and } \frac{\partial d^{*}}{\partial \beta}>0
$$

It appears that the convertibility restrictions encourage deposit accumulation (since fewer dollars are available to finance imports), while limits on cash will reduce the amount of deposits. This outcome is a result of the consumers being forced to hold more cash (and less money in deposits) in response to tightening requirements. ${ }^{37}$ It is interesting to see that the outcome of cash restrictions is the opposite of policymakers' intentions, that is to limit cash in circulation and boost deposit accumulation.

The analysis also sheds light on the welfare implications of observed financial sector distortions. It appears that cash shortages have an unambiguous negative impact on consumers' utility through the reduction of both components of consumption. The convertibility limits also have a welfare reducing impact. While it is not clear whether the aggregate consumption, $h^{*}+e g^{*}$, is reduced as a result of tightening of convertibility limits, contrasting the second inequality in (A-31) with (A-23) suggests that - given a level of money supply - aggregate consumption moves counter-cyclically with deposits, in response to changes in $\beta$. Therefore, given that $\frac{\partial d^{*}}{\partial \beta}>0$, it follows that $\frac{\partial\left(h^{*}+e g^{*}\right)}{\partial \beta}<0$, which implies a welfare-reducing impact of convertibility restrictions. ${ }^{38}$ Thus, while it is possible for domestic consumption to increase as a result of tighter convertibility limits, the overall welfare is reduced, because of a disproportionately greater fall in the consumption of imported goods. Needless to say, if

${ }^{37}$ As suggested earlier, it is convenient to think of coefficients $\alpha$ and $\beta$ as the length of time money must be held to finance consumption and secure conversion. It is, therefore, intuitive to note that in response to tightening cash limits, (i.e., more days to finance consumption), consumers are likely to held more cash, and less deposits.

${ }^{38}$ It could be shown that for all $h \geq e g$ (i.e., the value of domestically consumed goods is at least as large as that of imported goods, both measured in domestic currency), $\frac{\partial(h+e g)}{\partial \beta}<0$ also implies that $\frac{\partial(h \cdot g)^{\sigma}}{\partial \beta}<0$, which is a more precise indicator of the welfare-reducing impact of convertibility restrictions, given the utility function assumed in the paper. 
domestic and foreign goods are not perfect substitutes, the welfare loss from the reduction in imported consumption will be greater.

Despite the dampening impact of both types of restrictions on imports, they have different impacts on the current account. Since there is no (direct) impact from cash restrictions to output (and, therefore, exports) in the model, the impact on the current account would be through the impact on imports. The limits on convertibility, however, have an impact on aggregate production and exports, in addition to reducing imports, and therefore, have an ambiguous impact on the current account.

\section{Appendix III: Current Restrictions on Cash Withdrawal Abolished in October 2005}

The Resolution of the Cabinet of Ministers (CoM) No. 280 of August 5, 2002 "On Measures to Further Reduce Non-bank Money Turnover" (paragraph 3) stated that all economic entities-regardless of form of ownership-are granted the right to obtain cash from their bank accounts only up to the amount of cash earnings they have turned over. This Resolution also granted discretion to the CBU and the commercial banks to interfere with cash withdrawals.

CoM resolution No. 195 of May 19, 2000 "On Additional Measures to Promote Commercial Banks Participation in SME Development" (paragraph 1 and 3) and CoM resolution No. 390 of November 13, 2002 "On Measures to Stimulate Saturation of Market by Consumer Goods" stated that agro-processing enterprises as well as agricultural procurement organizations are allowed to withdraw cash only for their procurement needs.

CoM resolution No.29 of February 3, 1995 "On Streamlining of the Use of Cash Proceeds" (paragraph. 1) set limits on spending of proceeds in cash for urgent needs by types of entrepreneur activities: retail trade enterprises (up to 5 percent of total monthly turnover); catering enterprises (up to 4 percent of total monthly turnover); etc.

CoM resolution No.542 of December 31, 1998 "On Streamlining of System of Selling Oil Products, Liquid and Compressed Gas, Strengthening of Control over their Use" (paragraph 4) paved the way for legal entities to be allowed to withdraw cash for oil and gas purchases along with travel allowances for long-distance travel.

CoM resolution No.313 of June 24, 1999 "On Measures to Develop Nongovernment Kindergartens" (paragraph 5) stipulated that non-government kindergartens are allowed to spend only up to 15 percent of their derive revenues to purchase food in cash from agricultural markets and retail shops.

CoM resolution No. 172 of April 12, 2001 "On Measure to Secure the Development of Tanning Industry" (paragraph 4) stated that enterprises included in the tanning industry association are allowed to withdraw cash only up to 10 percent of their turnover to purchase accessory materials made by individual entrepreneurs.

CoM resolution No. 483 of October 23, 1997 "On Streamlining of Tax and Fee Levying from Physical Entities Involved in Entrepreneur Activities" (paragraph 1) instituted that individual entrepreneurs engaged in trade have the right to withdraw cash from their accounts only up to the amount of cash earnings they have turned over. 